\title{
Observation of Snowfall and Airflow over a Low Mountain Barrier
}

\author{
By Sento Nakai \\ National Research Institute for Earth Science and Disaster Prevention, Japan \\ and \\ Tatsuo Endoh
}

Institute of Low Temperature Science, Hokkaido University, Japan

(Manuscript received 1 October 1993, in revised form 12 January 1995)

\begin{abstract}
The characteristics of snowfall and airflow over a low mountain barrier (the Dewa Hills; the height of the ridge is about $0.6 \mathrm{~km}$ ) were investigated using a Döppler radar and rawinsondes. A sequence of snow clouds appeared accompanying a cold-front passage on 3 February 1990. Radar echoes were observed to pass over the Dewa Hills for about five hours, and they had diameters of tens of kilometers. The mixed-layer top was lowered and the wind was accelerated over the low mountain barrier, and the flow was considered to be 'subcritical' flow. The lowered mixed-layer top boundary suppressed the cloud- and echo-top height. The echoes contained the cells whose sizes were $5 \mathrm{~km}$ to $10 \mathrm{~km}$. The cells were accelerated by $3 \mathrm{~m} / \mathrm{s}$ when they were over the mountain barrier. The precipitation enhancement occurred over and as far as $10 \mathrm{~km}$ upwind of the mountain barrier. It is considered that the dominant process of the precipitation enhancement was a seeder-feeder process between the snow clouds and the clouds formed by the orographic lifting. On the lee side, colder air in the lowest layer suppressed descending flow and prevented the precipitation reduction by sublimation. It is considered that aggregation and melting mainly increased reflectivity on the lee side. In this case, the behavior of the snow clouds was strongly affected by the flow over the low mountain barrier, while the mean flow was not significantly modified from 'subcritical' flow by the existence of the snow clouds.
\end{abstract}

\section{Introduction}

The effect of orography on snow clouds appears in a variety of ways. For example, upward motion forced by the windward slope causes condensation and can lead to the growth of snow particles in the cloud, and the convergent flow and waves caused by mountains modify the structure of snow clouds.

The snow clouds in the satellite imagery and their radar echoes often show well-regulated patterns over the sea, such as, bands parallel/transversal to the low-level wind, spiral echoes and open cells (Sakakibara et al., 1988; Sanpei and Kawazoe, 1976). The echo pattern over the land has less regulated figures. The structure of the snow clouds over the land is expected to be different from that over the sea because of the lack of the supply of sensible and latent heat and the orographically forced airflow.

The flow over a mountain barrier in the dry condition is well investigated both theoretically and ob-

(C)1995, Meteorological Society of Japan servationally (Klemp and Lilly, 1975, 1978; Smith, 1979). However, when wet convection or precipitation exists, the flow is affected by clouds and shows different characteristics (Durran and Klemp, 1982). The interaction between the airflow forced by topography and the convection of snow clouds is not clear.

Recently, many researchers reported on orographically-affected wintertime precipitation. In the western United States and the Alpine area, the effects of high mountains are investigated observationally. Uttal et al. (1988) described the distribution of snow particles over the Park Range (among the Rocky Mountains) and inferred that the growth of the particles over the mountain along with the strong leeward downdraft results in intensified snowfall. Rauber (1992) showed by means of intense observations over the Sierra Nevada that cloud droplets grew to reach a diameter greater than $50 \mu \mathrm{m}$, resulting in riming growth and secondary ice-crystal 


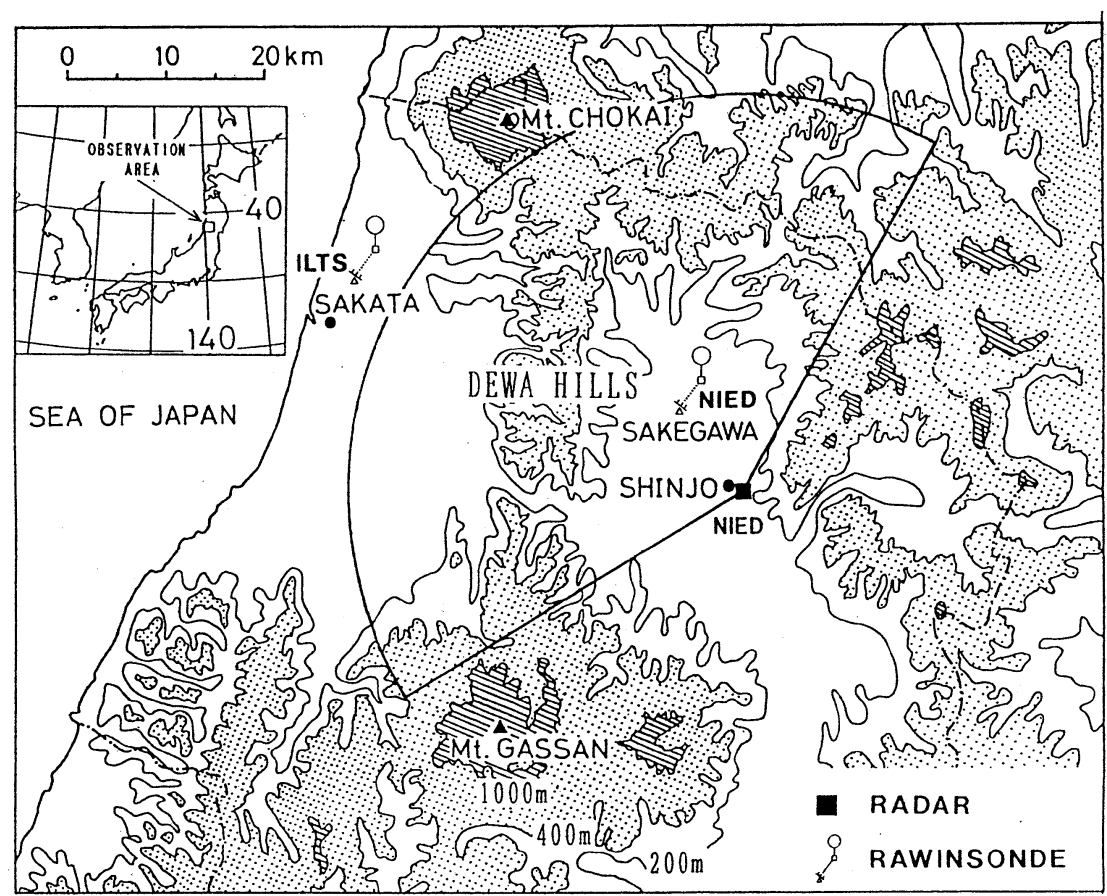

Fig. 1. Topography of the observation area and arrangement of the observation sites. The NIED Döppler radar site is shown by ' $\boldsymbol{\square}$ '. Effective coverage of the NIED Döppler radar is indicated by a sector. The rawinsonde launch sites are also shown (ILTS: Institute of Low Temperature Science, Hokkaido Univ). Meteorological observatories are shown by ' $\bullet$ '. Tobishima is located about $40 \mathrm{~km}$ northwest of Sakata.

production due to the rime splintering. Observations using dual-polarized radar were carried out in the northern Alpine area (Meischner et al., 1992). Model simulations over two-dimensional mountain ranges and over complex terrains were also carried out (Bruintjes et al., 1994; Meyers and Cotton, 1992).

The orographic effect on snow clouds developed over the Japan Sea has been studied in a variety of aspects. These studies are, for example, on the shift of the moving direction and concentration of snowfall (Kikuchi et al., 1987; Rikiishi et al., 1989; Yagi and Uchiyama, 1983), on the coastal effect (Takeda et al., 1982), on the role of topography as the trigger of snow cloud formation (Fujiyoshi et al., 1992), on the local snowfall concentration around the mountain ridge (Maki and Yagi, 1987), and on the seederfeeder process (Uyeda and Yagi, 1987). Snow clouds developed in the convergence zone between the winter monsoon and the land breeze were also investigated (e.g., Ishihara et al., 1989; Tsuboki et al., 1989). These studies showed a variety of processes included in the orographic effect.

Snow clouds landed on the Japan Sea coastal area typically pass over one to a few low mountain barriers before dissipation and sometimes cause heavy snowfall on inland areas. Observations of inland snowfall around a low mountain barrier were carried out as part of the Cooperative Japan Sea Snow
Cloud Project" from 1989 to 1993 in which the precipitation formation processes and airflow structures of snow clouds over the sea have been demonstrated (Ikawa et al., 1991; Murakami et al., 1994a; Yamada et al., 1994). The target mountain barrier is not as high as the Rocky Mountains and the Sierra Nevada. The stratification is characterized by a stable layer at a height of about $4 \mathrm{~km}$.

Some of the observed snow clouds showed an increase of the echo top over the Dewa Hills, while the other showed a decrease of the echo top. Nakai et al. (1990) analyzed a snow cloud of the former type and concluded that the convection was intensified. All snow clouds were of the latter type in the case we describe in this paper. The ground precipitation was not always in a solid phase but essentially the clouds were in the category of snow clouds. We present here the radar-echo structures and the wind field around the mountain barrier. We also present the difference of stratification between both sides of the mountain barrier.

\section{Observation and data}

Figure 1 shows the observation area with the locations of the facilities in February 1990. The Dewa Hills (the average height of the ridge is about $0.6 \mathrm{~km}$ ) divide the inland basin from the coastal plain. The winter Monsoon usually blows from the west or from the northwest, and snow clouds pass 
Table 1. Main specifications of the NIED Döppler radar.

\begin{tabular}{|c|c|}
\hline Retlector & $2 \mathrm{~m}$ aperture, circular parabola \\
\hline Beam width & 1. $2^{\circ}$ \\
\hline Rotation rate & $15 \mathrm{rom}$ (maximum) \\
\hline Antenne Scan & $\begin{array}{l}\text { PPI, RHI, CAPPI, Sector PPI. Sector RHI and } \\
\text { Positioning: programmable }\end{array}$ \\
\hline Frequency & $9415 \mathrm{MHz}$ \\
\hline Peak power & $40 \mathrm{~kW}$ \\
\hline Pulse length & $0.5 \mu \mathrm{s}$ \\
\hline $\begin{array}{l}\text { Pulse repetition } \\
\text { frequency. }\end{array}$ & $2000 \mathrm{~Hz}$ \\
\hline $\begin{array}{l}\text { Minimum detactable } \\
\text { signal }\end{array}$ & $-110 \mathrm{dBm}$ \\
\hline Maximum range & $40 \mathrm{~km}$ (extended to $64 \mathrm{~km}$ in 1991) \\
\hline Recorded data & $\begin{array}{l}\text { Reflectivity, Mean Doppler velocity, } \\
\text { Doppler spectrum width }\end{array}$ \\
\hline Spatial resolution & $\begin{array}{l}\text { Radial: } 250 \mathrm{~m}, \text { tangential: } 1.0^{\circ} / \\
\text { Radial: } 62.5 \mathrm{~m}, \text { tangential: } 0.5^{\circ}\end{array}$ \\
\hline $\begin{array}{l}\text { Reflectivity } \\
\text { sional processing }\end{array}$ & $\begin{array}{l}\text { Moving target indicator ON / OFF } \\
\text { Range correction ON / OFF }\end{array}$ \\
\hline Roflectivity resolution & $0.3 \mathrm{dBze}$ \\
\hline $\begin{array}{l}\text { Doppler } \\
\text { signal processing }\end{array}$ & Pulse pair processing \\
\hline Nyauist volocity & $\pm 16 \mathrm{~m} / \mathrm{s}$ \\
\hline Velocity resolution & $0.125 \mathrm{~m} / \mathrm{s}$ \\
\hline
\end{tabular}

over the Dewa Hills. The transportable Döppler radar of the National Research Institute for Earth Science and Disaster Prevention (NIED Döppler radar) was temporarily set at Shinjo and detected the radar echo signals from the precipitating hydrometeors above the Dewa Hills and the basin.

The main specifications of the NIED Döppler radar are shown in Table 1. Detailed specifications of the radar are described in Maki et al. (1989). A good feature of this radar is its very flexible scan control. We used scan control programs optimized for snow-cloud observations (Fig. 2) in this study. When many echoes appeared in the radar coverage, the "tracking mode" program or "standard mode" program was executed. A volume, vertical planes and a conical surface of data were acquired every 5 or 10 minutes. The data are composed of reflectivity, the Döppler velocity, and the Döppler spectrum width. When echoes decreased and another mass of echoes was expected to appear, the "monitoring mode" program was executed.

Two rawinsondes were released simultaneously at Sakata (upwind of the Dewa Hills) and at Sakegawa (downwind of the Dewa Hills). The distance between the two launch sites was $35 \mathrm{~km}$. The launchtime difference of the two rawinsonde was only 3 minutes.

Data from AMeDAS surface observation points and the operational upper-air observations of Akita were also used. Akita-is located $90 \mathrm{~km}$ north of Sakata on the coast of the Japan Sea. The stratification at Akita is qualitatively similar to that of the trockino mode 5. 3minut es / leycle

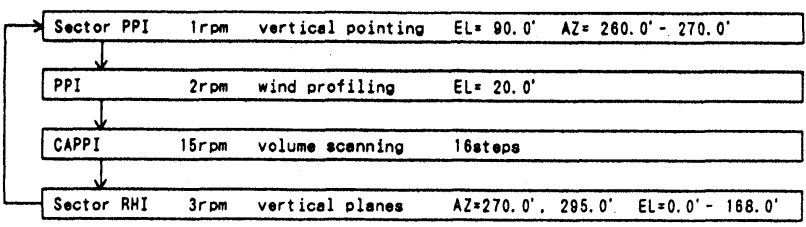

\begin{tabular}{|c|c|c|c|}
\hline Sector RHI & $2 \mathrm{rpm}$ & verticel plenes & $A Z=270.0^{\circ}, 295.0^{\circ}$ \\
\hline & & & \\
\hline CAPPI & $15 \mathrm{rpm}$ & volume scanning & 16st eps \\
\hline Sector RHI & $2 \mathrm{rpm}$ & vertical planes & $A Z=270.0^{\circ}, 295.0^{\circ}$ \\
\hline PPI & $2 \mathrm{rpm}$ & wind profiling & $E L=20.0^{\circ}$ \\
\hline & & & \\
\hline Sector PPI & Irpm & vertical pointing & $E L=90.0^{\circ} \quad A Z=180.0^{\circ}-270.0^{\circ}$ \\
\hline Sect or RHI & $2 \mathrm{rpm}$ & verticel planes & $A Z=270.0^{\circ}, 295.0^{\circ}$ \\
\hline PPI & $6 \mathrm{rpm}$ & ocho monit or ing & $E L=2.2^{\circ}$ \\
\hline
\end{tabular}

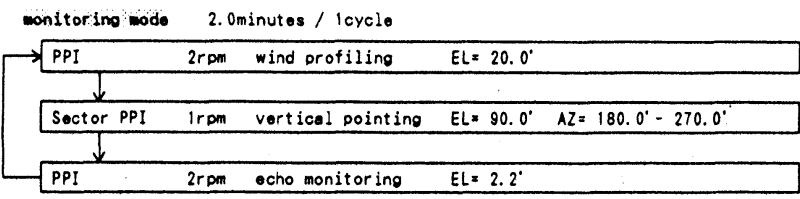

Fig. 2. Antenna scan programs for observations at Shinjo in February 1990. EL: elevation. AZ: azimuth. Elevations of CAPPI scan are $17.0^{\circ}, 15.4^{\circ}, 13.8^{\circ}$, $12.2^{\circ}, 10.8^{\circ}, 9.4^{\circ}, 8.0^{\circ}, 6.8^{\circ}, 5.6^{\circ}, 4.6^{\circ}$, $3.6^{\circ}, 2.8^{\circ}, 2.1^{\circ}, 1.5^{\circ}, 1.0^{\circ}$ and $0.6^{\circ}$.

study area.

\section{Synoptic conditions}

A surface weather map on 3 February 1990 is shown in Fig. 3. A cold front was located along the Pacific coast of the northern Japan at 21JST. It was in the middle of the Japan Sea at 09JST, and it passed the observation area between 09JST and 21JST

The temperature, wind, sunshine duration and precipitation at Tobishima Island (located at about $40 \mathrm{~km}$ northwest of Sakata), Sakata and Shinjo are shown in Fig. 4. The precipitation was observed between 15JST and 22JST. AMeDAS hourly precipitation distribution of the observation area indicated that the precipitating area moved eastward, corresponding to the passage of the cold front. Temperatures rose or dropped when precipitation was observed as well as by surface heating or the diurnal change (Fig. 4). Moreover, the wind direction changed corresponding to the temperature changes (Fig. 4). Temperatures dropped by $3^{\circ} \mathrm{C}$ and the wind direction changed to northwesterly between 15JST and 17JST at Tobishima. Temperatures rose by $2^{\circ} \mathrm{C}$ and the wind direction changed to north- 


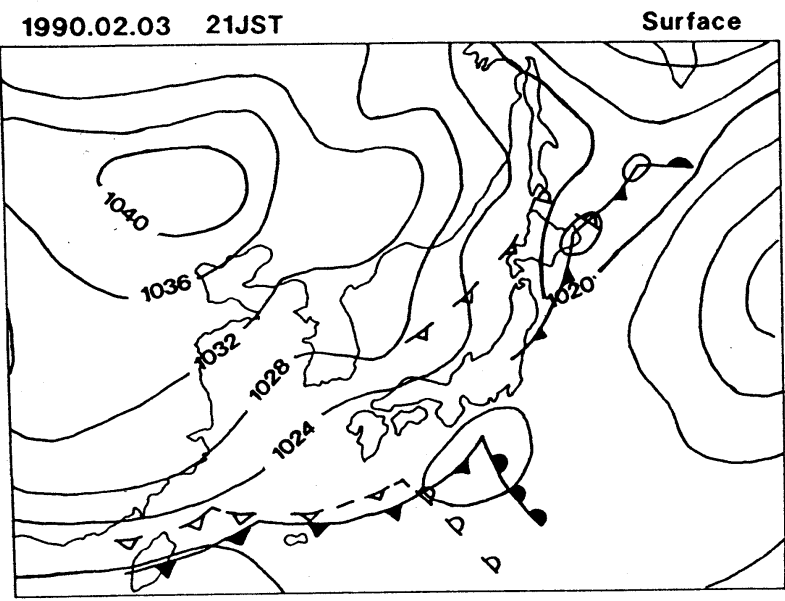

Fig. 3. Surface weather map at 21JST, 3 February 1990. Fronts at 09JST, 3 February 1990 are shown by open marks and broken lines.

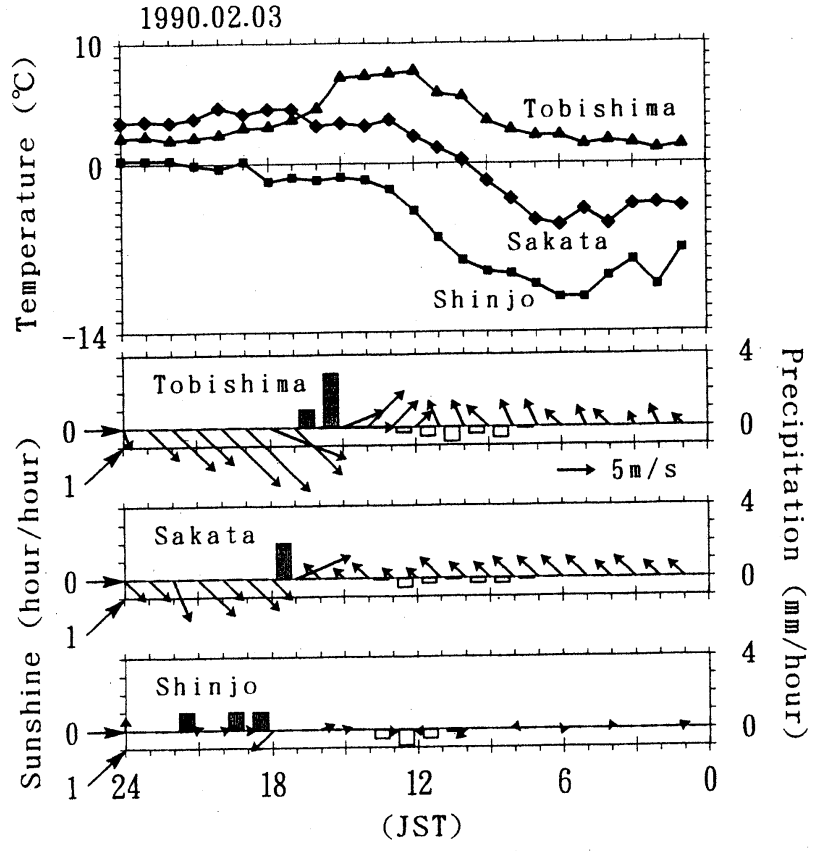

Fig. 4. Wind, temperature, hourly precipitation, and hourly ratio of sunshine $\mathrm{du}-$ ration in 3 February 1990 at Tobishima, Sakata and Shinjo from the AMeDAS surface observation data. The wind is shown by a vector. Precipitation is expressed by striped bars extending upward, and the ratio of sunshine duration by white bars extending downward.

westerly between 16JST and 18JST at Sakata. Temperatures rose by $2^{\circ} \mathrm{C}$ between 18JST and 19JST at Shinjo. All of these coincided with the passage of the cold front, although the-temperature rose at Sakata and Shinjo.

The wind blew from the southeast before the tem-
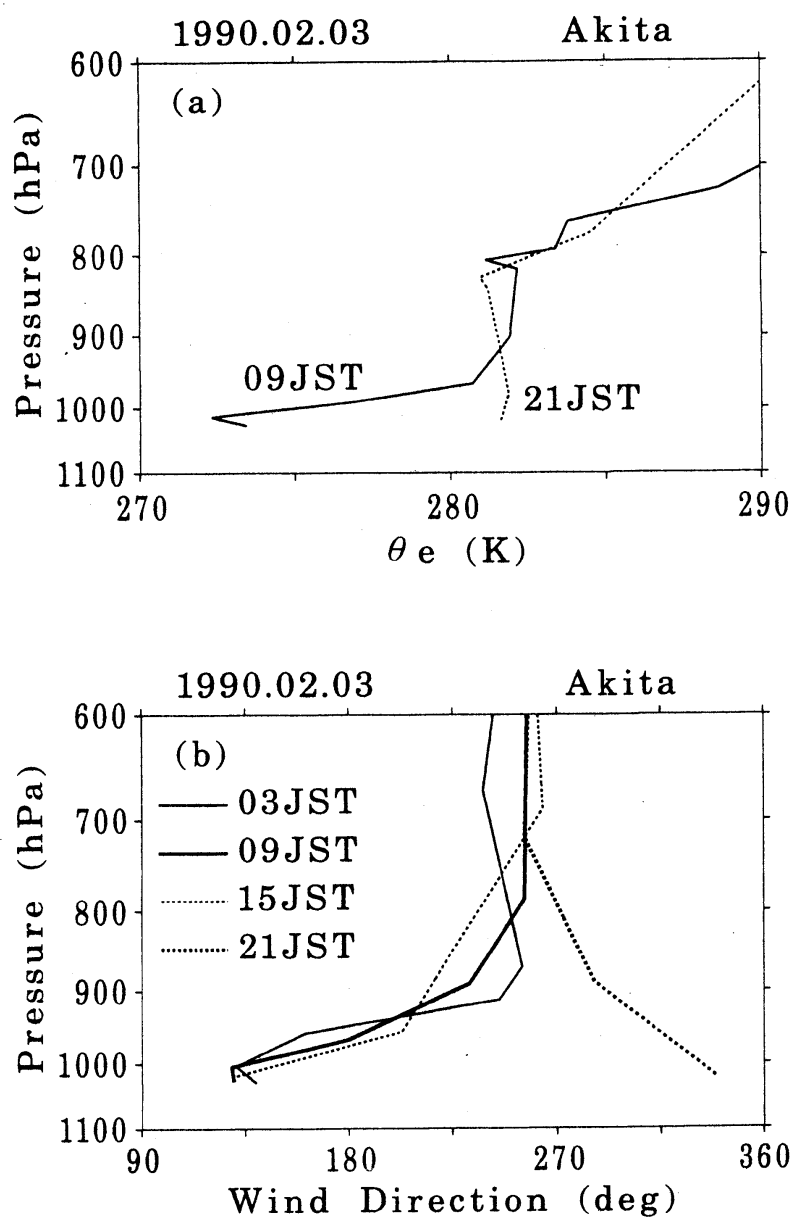

Fig. 5. Vertical profiles at Akita on 3 February 1990; (a) equivalent potential temperature; (b) wind direction.

peratures rose at Sakata. At Tobishima, temperatures rose by $2^{\circ} \mathrm{C}$ and the wind direction changed from southeasterly to southwesterly with no precipitation between 11JST and 12JST (Fig. 4). These suggest that the colder air blew from the land to the Japan Sea at Tobishima and at Sakata before the cold front passage. The profiles of the equivalent potential temperature $\left(\theta_{e}\right)$ and wind direction at Akita (Fig. 5) also indicate that the colder air blew to the Japan Sea. The equivalent potential temperature (Fig. $5 \mathrm{a}$ ) rose by $9^{\circ} \mathrm{C}$ near the ground level between 09JST and 21JST, and the wind direction (Fig. 5b) changed from southeasterly to northwesterly near the ground level between 15JST and 21JST.

The change of temperature and wind direction at 11-12JST at Tobishima corresponded to the retreat of the colder air from the land; that at 15-17JST corresponded to the passage of the cold front. The changes at 16-18JST at Sakata and that at 1819JST at Shinjo corresponded to the direct transition from the colder air to the post cold-frontal air without the appearance of warm air before the 


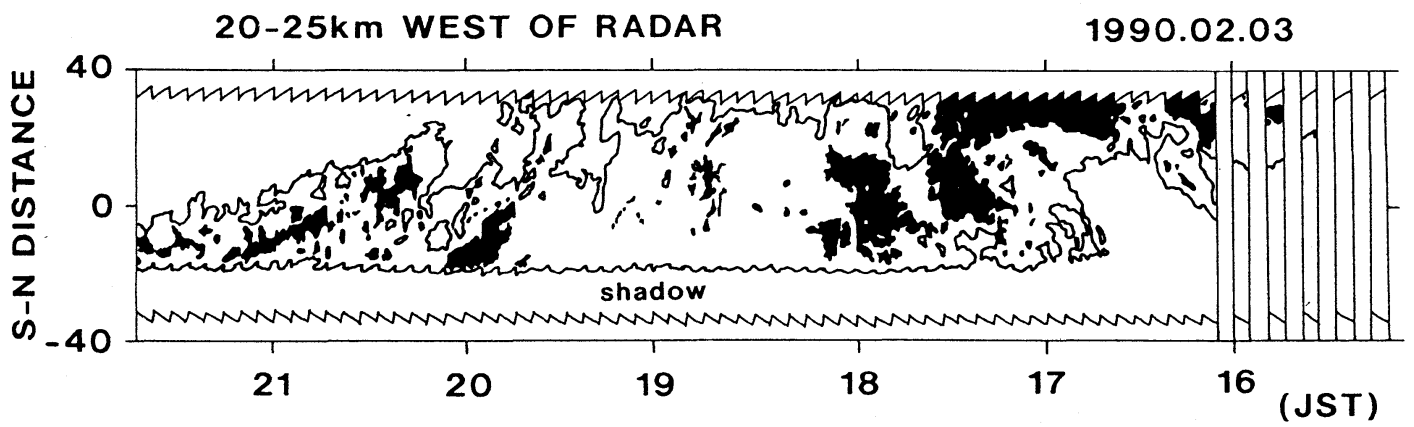

Fig. 6. Time-latitude cross section of reflectivity at a height of $1.5 \mathrm{~km}$ from 16JST to 21JST on 3 February 1990. Each strip extends from $40 \mathrm{~km}$ south to $40 \mathrm{~km}$ north, and $20-25 \mathrm{~km}$ west of the radar. Contour lines and black areas show $14 \mathrm{dBZe}$ and stronger than $20 \mathrm{dBZe}$, respectively. Data intervals are 5 minutes except 10-minute intervals before 1605JST.

front. Precipitation accompanied the passage of the cold-front but did not accompany the retreat of the colder air from the land.

\section{Precipitation accompanying the cold front passage}

\section{a. Pattern and the motion of radar echoes}

Radar echoes accompanying the cold front appeared mainly between 16JST and 21JST. Figure 6 is a time section of the radar echo from $20 \mathrm{~km}$ to $25 \mathrm{~km}$ to the west of the radar. Many echoes were observed to pass over the Dewa Hills that have a two-dimensional nature $(-5 \mathrm{~km}$ to $25 \mathrm{~km}$ in S$\mathrm{N}$ distance of Fig. 6). The echoes had the size of a few to several tens of kilometers and the shapes were highly irregular. We refer to these echoes as massive echoes and show an example in Fig. 7. We defined echo cells in the massive echoes as a part of an echo whose size was $5 \mathrm{~km}$ to $10 \mathrm{~km}$ keeping the shape in a sequence of CAPPI images as indicated by closed circles in Fig. 7 . Five echo cells are shown in Fig. 7 denoted by 'a', 'b', 'c', 'd' and 'e', except 1719JST and 1740JST when echo cells ' $a$ ' and 'e' were not identified, respectively.

We found two echoes other than the massive echoes. One was a stationary echo which appeared above the southern slope of Mt. Chokai (1630JST1730JST, $20 \mathrm{~km}$ to $40 \mathrm{~km}$ in Fig. 6), when the surface wind at Sakata was southwesterly (Fig. 4). Another was a sequence of fragmentary echoes above the northern slope of Mt. Gassan (2117JST,$-20 \mathrm{~km}$ to $0 \mathrm{~km}$ in Fig. 6). This type of echo continued to appear at the same location at least until 2245JST. The wind at Tsuruoka $(20 \mathrm{~km}$ south of Sakata) was northwesterly from 21JST to 23JST. Either of these echoes appeared when the surface wind near the echo was favorable for orographic lifting.

Figure 8 shows the direction and speed of the echo motion between 16JST and 21JST. The echo motion was decided by subjective tracking of the whole of the massive echoes in the radar coverage using a pair of CAPPI images of 5 or 10 minutes interval. The direction of echo motion had no significant change during the 5 hours and the speed increased by $3 \mathrm{~m} / \mathrm{s}$ after 19JST. The vector mean of the echo motion was $17.2 \mathrm{~m} / \mathrm{s}$ and $81.0^{\circ}$. The direction of the echo motion differed by $70^{\circ}$ from, or was near perpendicular to the running direction of the Dewa Hills.

The apparent motion of the massive echoes (Fig. 8) varied with a period of about thirty minutes, except from 18JST to 19JST when the fluctuation was not clear. The amplitude was $3 \mathrm{~m} / \mathrm{s}$ to $6 \mathrm{~m} / \mathrm{s}$. The speed of the echo motion tended to decrease or begin to decrease when the massive echoes became located over the Dewa Hills (Fig. 6). The maxima of the speed reflect the acceleration of the front and rear edges of the massive echoes. The minima of the speed result from the deceleration and dissipation of the front part of the massive echoes on the lee side.

The cell motion was decided in the same way as the echo motion but for the cells existing in the massive echoes between $-5 \mathrm{~km}$ to $25 \mathrm{~km}$ in the S-N direction of Fig. 6. The directions of the cell motion were close to the echo motion throughout the 5 hours and had no significant change. The speeds of cell motion were scattered significantly but the result of least-square approximation showed that the cell motion was faster than the echo motion throughout the 5 hours. The vector mean of the cell motion was $20.6 \mathrm{~m} / \mathrm{s}, 79.1^{\circ}$. The difference of the speed is attributed to the forward relative motion of the cells in the massive echoes. In Fig. 7, the cells indicated by closed circles come apart gradually from the arrow representing the mean echo motion, while the motion of the massive echo was close to the mean echo motion. The locations of the cells, which was far from the front of the massive echo at 1719JST, were almost at the front of the echo at 1740JST. The difference of the speed of echo motion and that of cell motion also results from the decay of old cells 


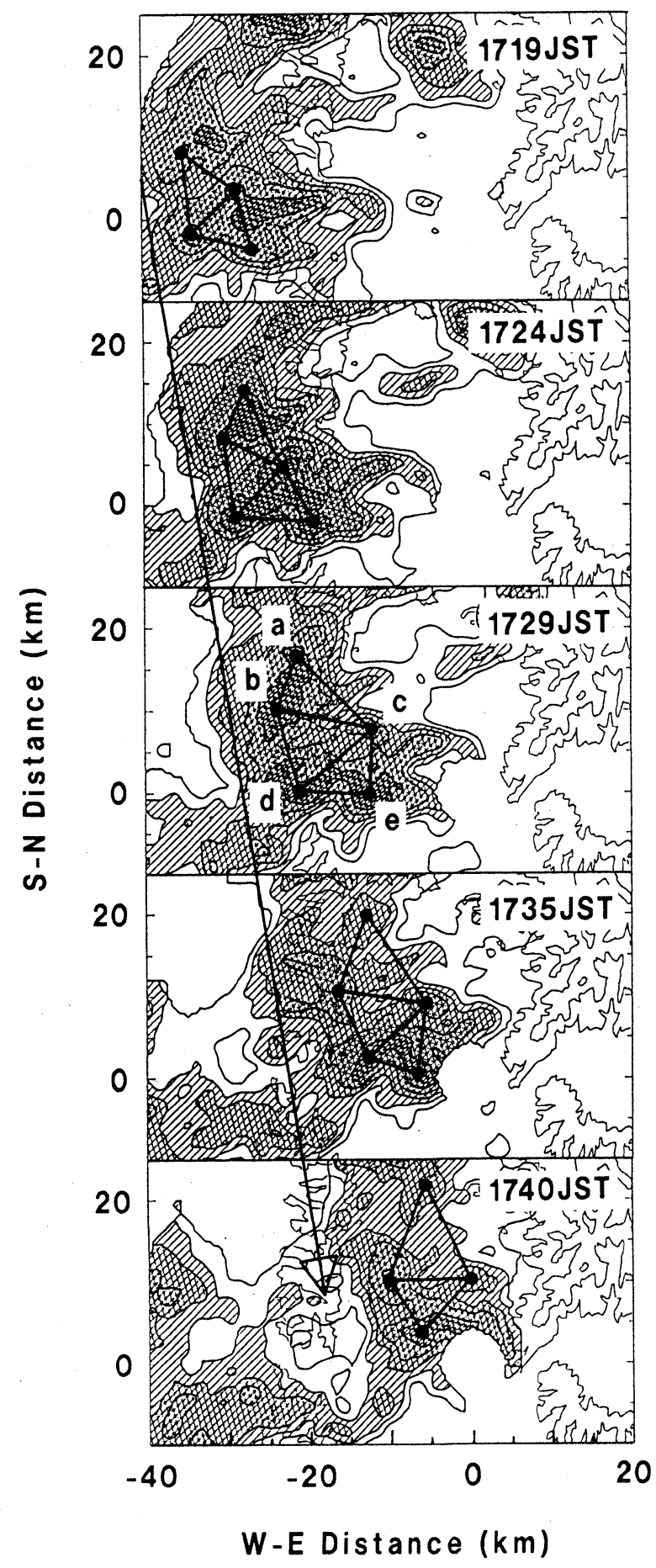

Fig. 7. Time-series of the horizontal section at the height of $1.6 \mathrm{~km}$. Closed circles denote the locations of echo cells. The mean echo motion is indicated by a long arrow.

at the front of the echo, and from the new cell formation at the rear of the echo over the Dewa Hills (Nakai and Endoh, 1992).

The cells in the massive echoes showed a characteristic motion. The cells in Fig. 7 are connected

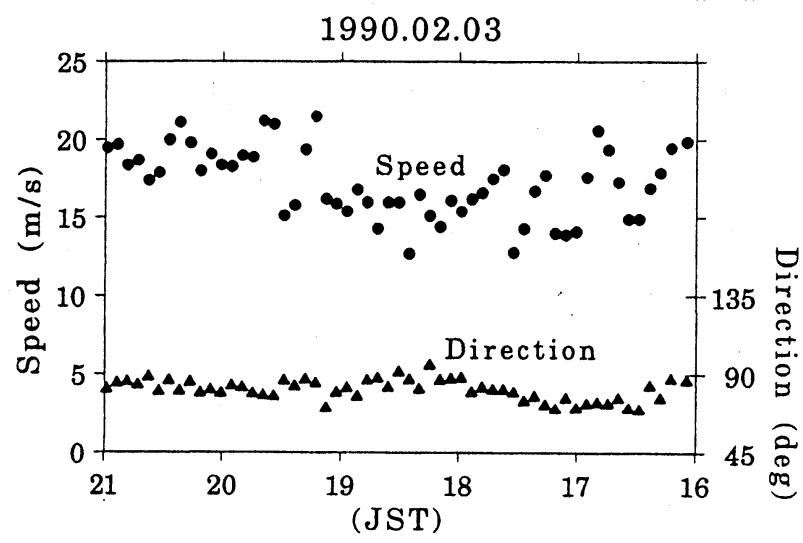

Fig. 8. Moving speed and direction of radar echoes around the Dewa Hills derived by a subjective matching of two echo patterns at 5 -minute intervals.

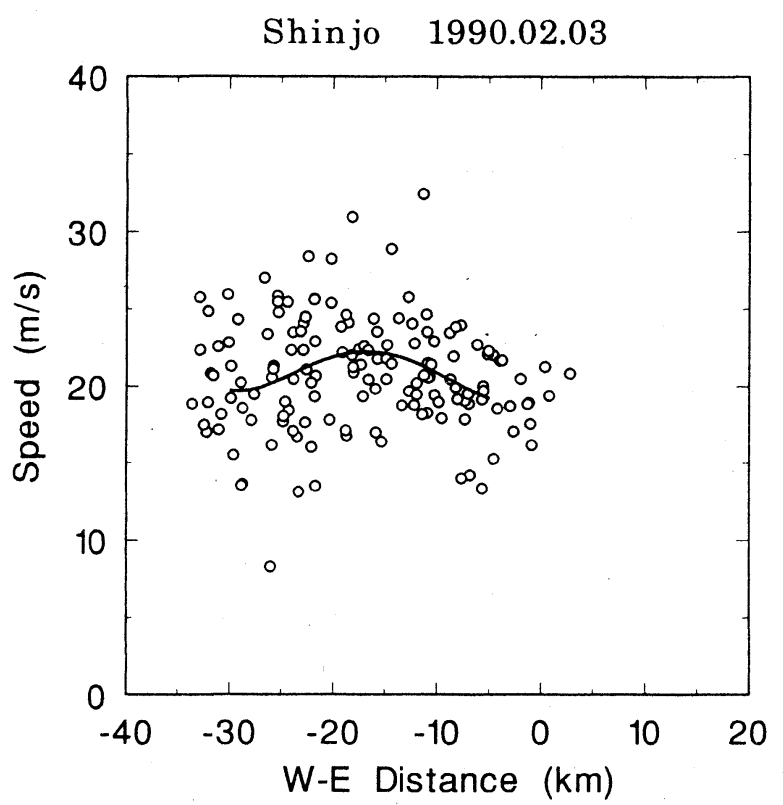

Fig. 9. The speed of cells versus W-E distance. The solid line indicates the result of least-square approximation.

by solid lines and the change of relative position is seen as the deformation of the triangles. Cell ' $e$ ' moved faster than other cells between 1719JST and 1724JST and the triangle constructed by Cells ' $c$ ', ' $d$ ' and 'e' elongated in W-E direction. Cell 'c' moved faster and Cell 'e' did not, between 1724JST and 1729JST. The Cells 'a', 'b' and 'd' moved faster after 1729JST. All cells accelerated only between $-25 \mathrm{~km}$ to $-10 \mathrm{~km}$ in the W-E direction. Figure 9 shows the speeds of all tracked cells versus $\mathrm{W}-\mathrm{E}$ distance. The result of a least-square approximation showed that the speed of the cell motion had a peak around $-17 \mathrm{~km}$, which is over the ridge of the Dewa Hills (Fig. 9). The peak speed reaches 

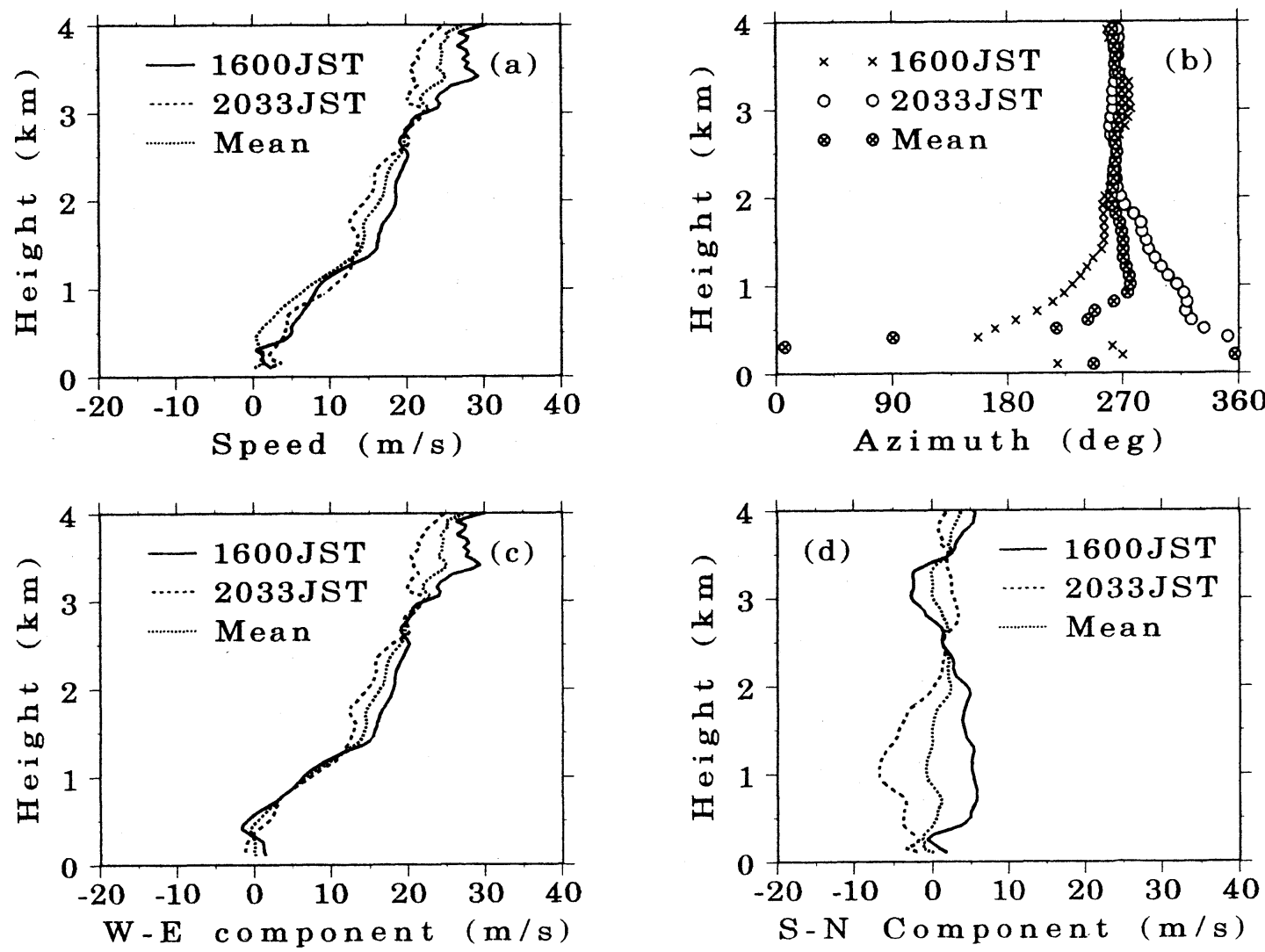

Fig. 10. Wind profiles based on Sakegawa rawinsonde observations. 'Mean' indicates the vector mean of the two observed profiles at each height, (a): wind speed, (b): wind direction, (c): W-E component, (d): S-N component.

$22.3 \mathrm{~m} / \mathrm{s}$ and is larger by about $3 \mathrm{~m} / \mathrm{s}$ than the either side of the Dewa Hills. It is considered that the orographic effect causes the acceleration of the cells in the massive echoes.

The mean echo motion and the mean cell motion were compared with the wind profile from rawinsonde observations at Sakegawa. Wind-profile data at Sakata were not used because of considerable noise in the data. The wind speed at 1600JST was similar to that at 2033JST (Fig. 10a), but the wind directions were different below the height of $2 \mathrm{~km}$ (Fig. 10b). The difference was due to the change of the S-N component (Fig. 10d). The W-E component and the wind speed were qualitatively the same (Fig. 10a, 10c) and the absolute values of the S-N components are small. So we use the vector mean of the two wind profiles for the qualitative analysis neglecting the difference of the S-N component.

The mean wind speed increased smoothly with height and the mean wind direction was almost constant above the height of $0.9 \mathrm{~km}$. The mean echo speed agreed with the mean wind speed at the height of $2.2 \mathrm{~km}$. The direction of the mean echo motion does not differ from the mean wind direction by more than $5^{\circ}$ between the heights of $1.8 \mathrm{~km}$ and $2.8 \mathrm{~km}$. The mean cell motion is close to the mean wind at the height of $2.8 \mathrm{~km}$, though it was too high to be considered as the steering level, considering that the depth of the mixed layer was $3.6 \mathrm{~km}$ at Sakegawa. The speed of the mean cell motion was faster than the middle mixed-layer wind. It is considered that the massive echoes were steered by the wind of the middle mixed layer and the cell motion was deviated from the wind due to the forward cell motion relative to the massive echoes (Fig. 7).

\section{b. Distribution of precipitation aloft}

In this subsection, the effect of the Dewa Hills on the distribution of total precipitation aloft is described using reflectivity data. First, we got the frequencies at the height of $1.6 \mathrm{~km}$ (Fig. 11), which is considerably lower than the echo-top height of the massive echoes, and at which the shadow area is smallest, using 56 sequential CAPPI data from 16JST to 21JST at five minute intervals. The frequency of moderate to strong echo was defined at each grid point as the number of times that the reflectivity exceeds $15 \mathrm{dBZe}^{1}$. The frequency of strong

1 We used a constant value for water or 0.93 as the parameter $|K|^{2}=\left|m^{2}-1 / m^{2}+2\right|^{2}$ in the calculation of dBZe, where $m$ is the complex index of refraction. The dBZe values in this paper are smaller by 6.74 than the dBZe values calculated using $|K|^{2}$ for ice or 0.197 . 
(a)

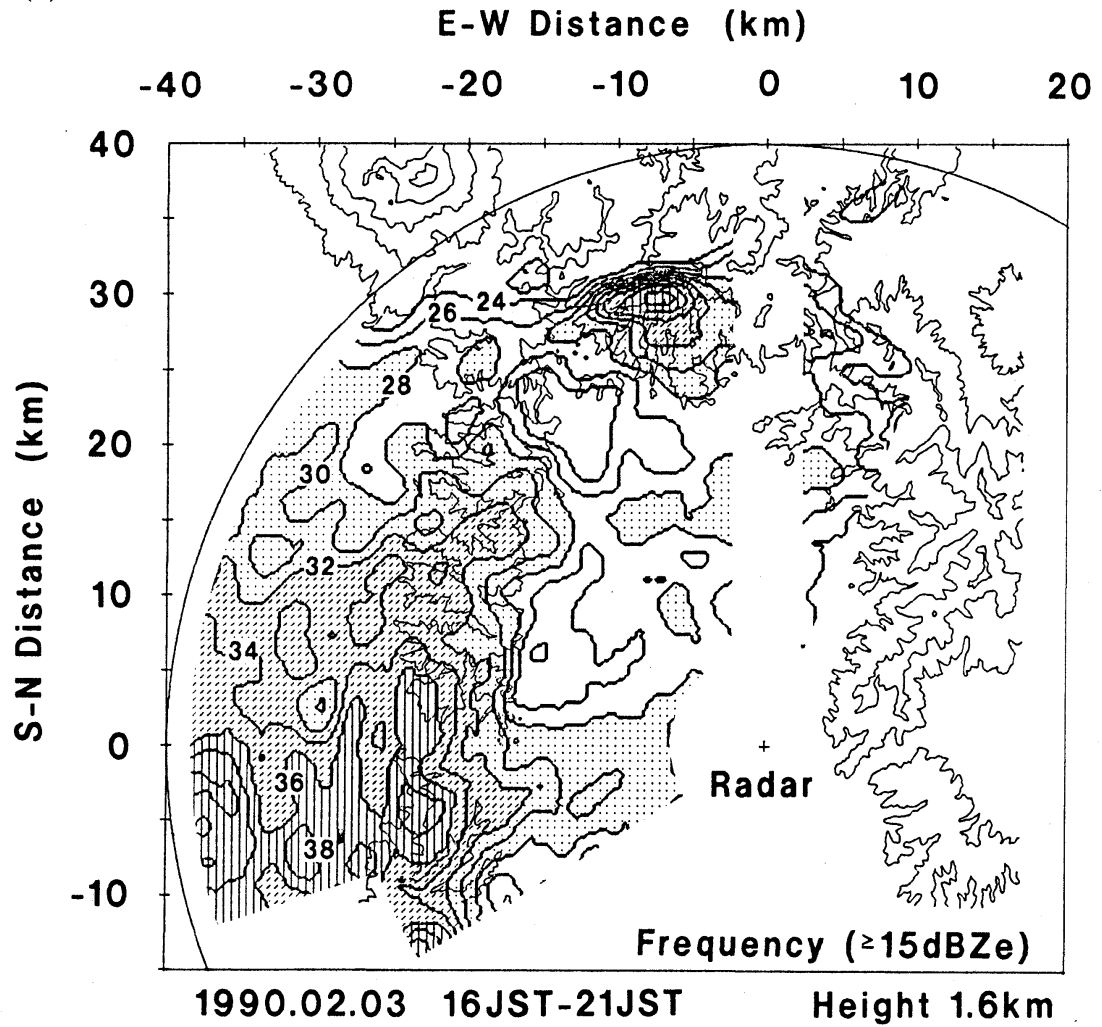

(b)

\section{E-W Distance $(\mathrm{km})$}

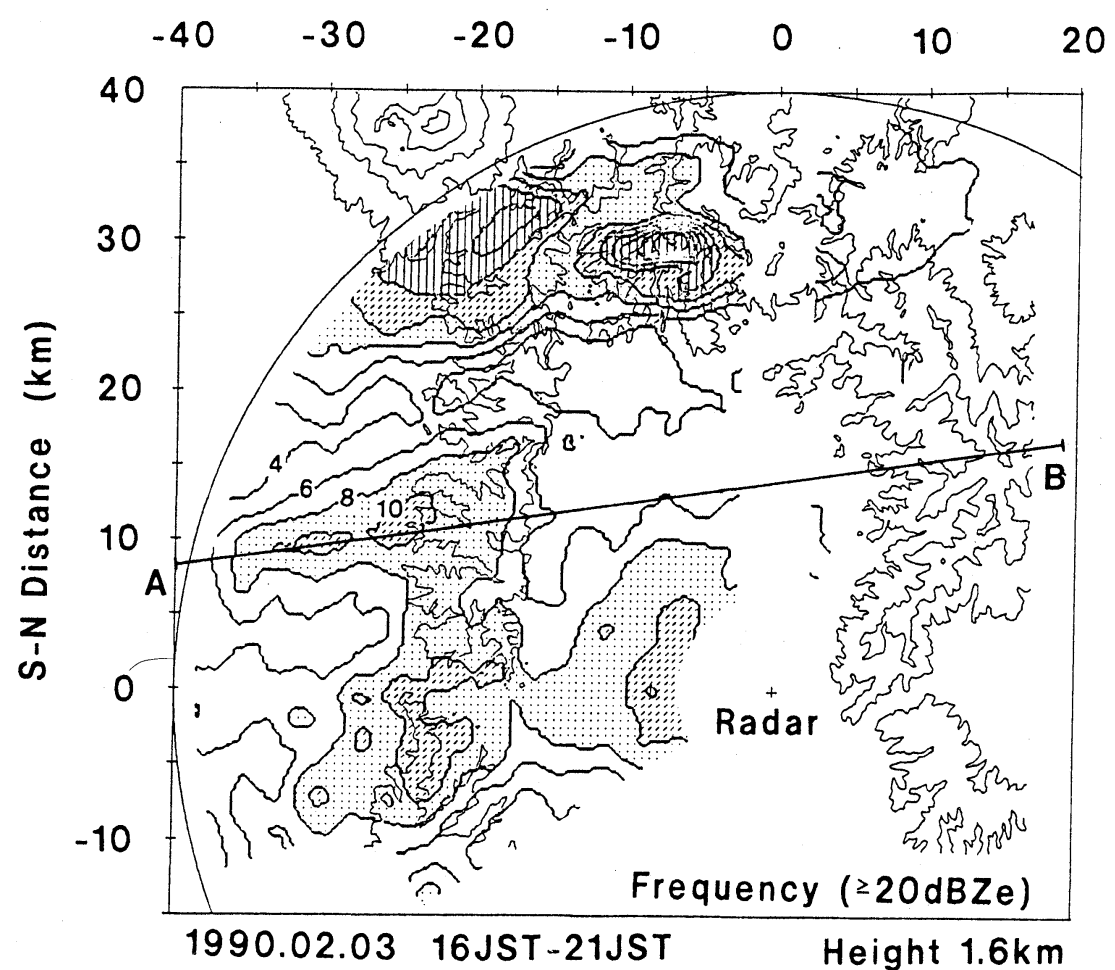

Fig. 11. (a): Frequency of moderate to strong echoes (reflectivity greater than $15.0 \mathrm{dBZe}$ ) among 56 CAPPI data at five-minute intervals from 16JST to 21JST at a height of $1.6 \mathrm{~km}$. The large frequency around $-5 \mathrm{~km}$ in W-E distance, $30 \mathrm{~km}$ in S-N distance is due to ground clutter through antenna sidelobes. (b): Same as (a) but for strong echoes (reflectivity greater than 20.0dBZe). 

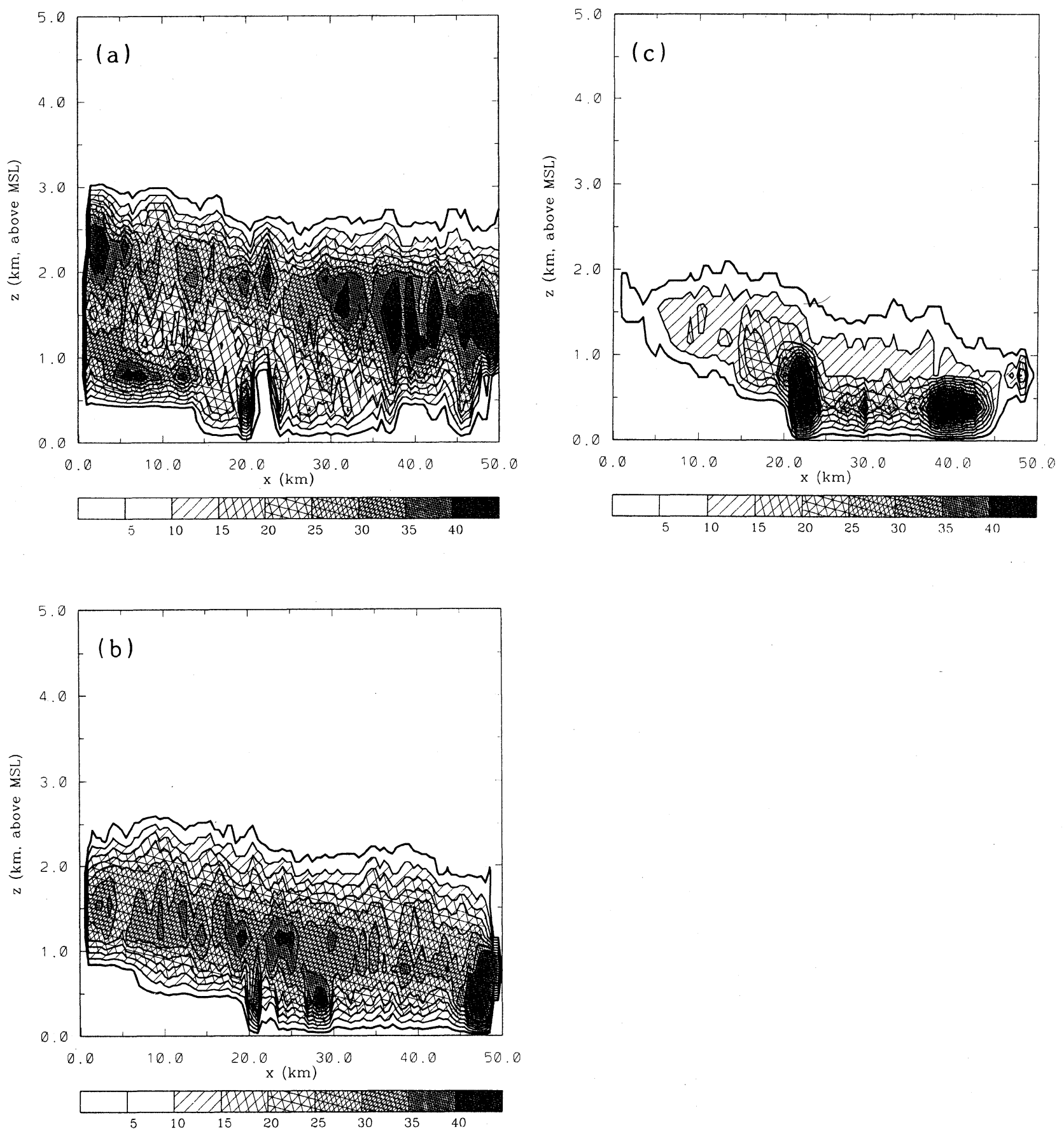

Fig. 12. (a): The relative frequency of occurrence of reflectivity Level 1 from 16JST to 21JST on the vertical plane along the line shown in Fig. 11b. (b): Same as (a) but for reflectivity Level 2. (c): Same as (a) but for reflectivity Level 3.

echo was defined analogously for $20 \mathrm{dBZe}$.

A moderate to strong echo appeared frequently on the windward side of the Dewa Hills (Fig. 11a). The maxima of the frequency appeared near Mt. Gassan and had a value in excess of 38 times, or $68 \%$ of the total number of data. The frequency rapidly decreased over the Dewa Hills $(-20 \mathrm{~km}$ to $-15 \mathrm{~km}$ in Fig. 11a) and a minimum appeared on the lee side $(-15 \mathrm{~km}$ in $\mathrm{W}-\mathrm{E}$ distance and $6 \mathrm{~km}$ in $\mathrm{S}$ $\mathrm{N}$ distance). The frequency difference between both sides of the Dewa Hills was up to 14, corresponding to $25 \%$ of the total number of data. Notice that the rapid frequency decrease is seen from $-10 \mathrm{~km}$ to $30 \mathrm{~km}$ in the $\mathrm{S}-\mathrm{N}$ direction along the Dewa Hills. It strongly suggests that the Dewa Hills affected the distribution of precipitation. 
The frequency of strong echoes shows different characteristics. The maxima of the frequency mainly appeared over the Dewa Hills (Fig. 11b). The difference between the maxima and the frequency on the windward side is 4 to 6 times, suggesting that the precipitation enhancement occurred when snow clouds passed over the Dewa Hills. A maximum at $-20 \mathrm{~km}$ in the $\mathrm{W}$-E direction, $30 \mathrm{~km}$ in the S-N direction, is considered to be due to the strong influence of Mt. Chokai and not representative of the massive echoes which passed over the Dewa Hills. Another maximum at $-8 \mathrm{~km}$ in the WE direction, $30 \mathrm{~km}$ in the $\mathrm{S}-\mathrm{N}$ direction, was due to ground clutter through antenna sidelobes. A maximum at the central part of the leeward basin is considered to be formed by the growth of snow particles by aggregation, as discussed later, and possibly influenced by the mountains located to the leeward.

Next, we examined the vertical distribution of the relative frequency of various reflectivity levels along the direction of the mean echo motion. This direction was near to the direction of the mean wind (Fig. 10b) and mean cell motion, and nearly perpendicular to the running direction of the Dewa Hills. We defined the reflectivity level as

Level 1: 14.0dBZe $\leq$ (reflectivity) $<17.0 \mathrm{dBZe}$

Level 2: 17.0dBZe $\leq$ (reflectivity) $<20.0 \mathrm{dBZe}$

Level 3: 20.0dBZe $\leq$ (reflectivity)

and calculated the relative frequency of occurrence of each level. Figure 12 shows the distribution of relative frequency on a vertical plane along the line A-B shown in Fig. 11b. The distance along the line and the height above the mean sea level are referred to as $x$ and $z$, respectively. We examined other planes crossing the Dewa Hills at different locations and found that the basic features were similar. So we present here the results of the analysis of one plane.

A $5 \%$ contour line of reflectivity Level 1 (Fig. 12a) was at $z \sim 3.0 \mathrm{~km}$ on the windward side, lowered abruptly over the Dewa Hills at $x=17 \mathrm{~km}$, and was almost constant at $z \sim 2.6 \mathrm{~km}$ on the lee side. Other contour lines at $z>2.0 \mathrm{~km}$ showed similar characteristics. These contour lines suggest that the snow particles were suspended on the lee side by updrafts, on average large enough to offset the falling velocity. The maxima of relative frequency existed at $z=2.0 \mathrm{~km}$ and $z=2.4 \mathrm{~km}$ decreasing in height with $x$ on the windward side, at $z=2.0 \mathrm{~km}$ over the Dewa Hills, and at $z=1.6 \mathrm{~km}$ on the lee side. An area of low relative frequency (less than $25 \%$ ) existed at $5 \mathrm{~km}<x<20 \mathrm{~km}, 1.0 \mathrm{~km}<z<1.8 \mathrm{~km}$. The maxima centered at $(x, z)=(8 \mathrm{~km}, 0.8 \mathrm{~km})$, $(12 \mathrm{~km}, 0.8 \mathrm{~km}),(20 \mathrm{~km}, 0.4 \mathrm{~km}),(49 \mathrm{~km}, 1.2 \mathrm{~km})$ are false. They indicate the weak signal caused by the radar beam partially interrupted by the topography.
The maxima of relative frequency of reflectivity Level 2 (Fig. 12b) existed between $z=1.2 \mathrm{~km}$ and $z=1.6 \mathrm{~km}$ on the windward side, at $z=1.2 \mathrm{~km}$ over the Dewa Hills, and below $z=1.2 \mathrm{~km}$ on the lee side. The height of the maxima decreased with $x$. The values of the maxima over the Dewa Hills exceeded $40 \%$ and was slightly larger than that of other maxima. The maxima centered at $(x, z)=$ $(20 \mathrm{~km}, 0.4 \mathrm{~km}),(28 \mathrm{~km}, 0.4 \mathrm{~km}),(48 \mathrm{~km}, 1.0 \mathrm{~km})$ are false. They indicate the weak signal or clutter caused by the topography.

The distribution of the echoes of reflectivity Level 3 (Fig. 12c) was clearly different between both sides of the Dewa Hills. The echoes of this level appeared mainly at $5 \mathrm{~km}<x<16 \mathrm{~km}, 1.0 \mathrm{~km}<z<2.0 \mathrm{~km}$ on the windward side, and the relative frequency was less than $20 \%$. Over the Dewa Hills, it appeared $z<2.0 \mathrm{~km}$ and the relative frequency was less than $25 \%$, larger than that on the windward side. The echoes of this level appeared at $z<1.5 \mathrm{~km}$ on the lee side and the relative frequency slightly increased with decreasing height. The outstanding maxima below $1.0 \mathrm{~km}$ are ground clutter. The large relative frequency seen at $x>25 \mathrm{~km}, z=0.4 \mathrm{~km}$ indicates melting of snow particles.

The relative frequencies of different reflectivity levels are related to each other. The area of low relative frequency of reflectivity Level 1 on the windward side and over the Dewa Hills collocated with the area of high relative frequency of reflectivity Level 2, where the echoes of reflectivity Level 3 appeared. This indicates that the reflectivity increased from Level 1 to Level 2 and 3 by the growth of snow particles, that is, the precipitation enhancement occurred. The area of precipitation enhancement extended as far as $10 \mathrm{~km}$ upwind of the Dewa Hills and up to $z=2.0 \mathrm{~km}$ on this plane, where orographic lifting was expected. The relative frequency of reflectivity Level 1 was high at $z>2.0 \mathrm{~km}$, and precipitation enhancement did not dominate there.

On the lee side, the area of high relative frequency of reflectivity Level 2 located at lower heights than that of reflectivity Level 1. Reflectivity Level 3 mainly appeared at much lower heights. This indicates the increase of reflectivity with decreasing height. It is suggested that the falling snow particles grew mainly by aggregation above the melting level, because orographic upward motion and resulting generation of cloud droplets are not expected here.

c. Orographic flow and its effect on the snow clouds

The mean horizontal velocity during this period on a vertical plane along a $295^{\circ}-115^{\circ}$ line was calculated neglecting the contribution of vertical motion to the Döppler velocity (Fig. 13). The distance along the line and the height above the mean sea level are referred to as $x^{\prime}$ and $z$, respectively. The horizontal 


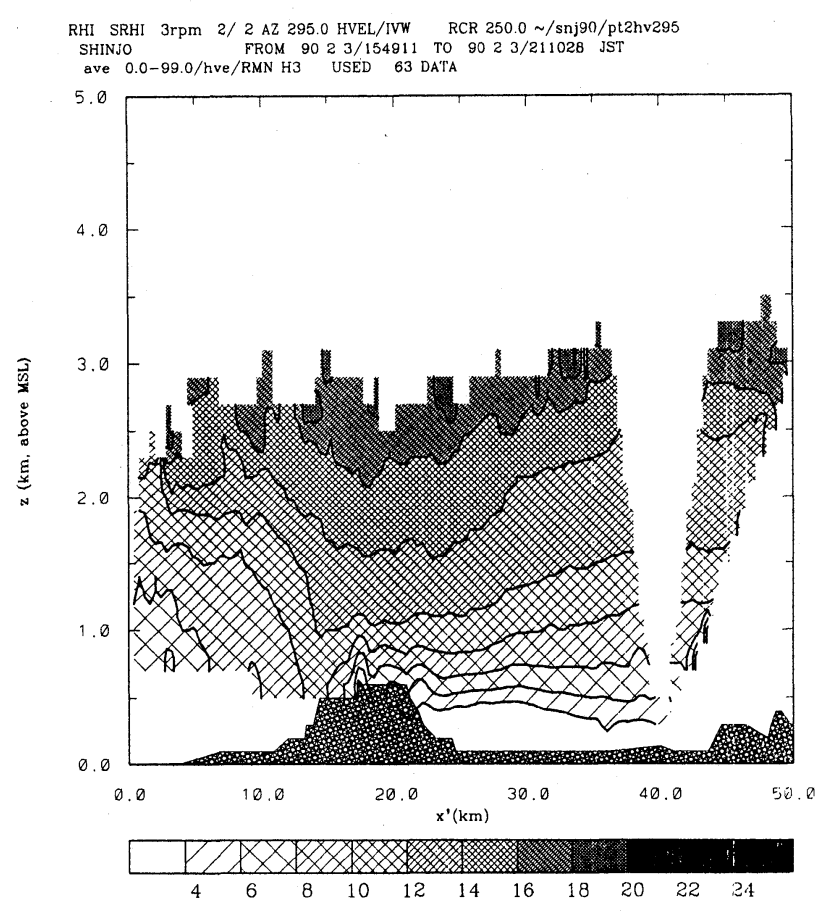

Fig. 13. Mean horizontal velocity at 5 -minute intervals of the $58 \mathrm{RHI}$ data at an azimuth of $295^{\circ}$ from 16JST to 21JST.

velocity was not calculated when the elevation was more than $40^{\circ}$ because the vertical motion became no longer negligible.

The mean horizontal velocity increased by about $4 \mathrm{~m} / \mathrm{s}$ over the Dewa Hills as well as it increased with height. A rapid increase is seen from $x^{\prime}=10 \mathrm{~km}$ to $x^{\prime}=14 \mathrm{~km}$ at $z=1.0 \mathrm{~km}$ and to $x^{\prime}=18 \mathrm{~km}$ at $z=2.0 \mathrm{~km}$, and the velocity gradually decreased on the lee side but stayed faster than the original value. The increase of the mean horizontal velocity coexisted with the acceleration in mean cell motion mentioned in Subsection 4a. It is considered that the acceleration in the cell motion is caused by the increase of the wind over the Dewa Hills.

The wind speed parallel to this plane calculated from the mean wind profile (Fig. 10) was $12.9 \mathrm{~m} / \mathrm{s}$ at $z=1.5 \mathrm{~km}, 13.9 \mathrm{~m} / \mathrm{s}$ at $z=2.0 \mathrm{~km}$, and $16.7 \mathrm{~m} / \mathrm{s}$ at $\mathrm{z}=2.5 \mathrm{~km}$. It qualitatively agreed with the mean horizontal velocity at $x^{\prime}=32.8 \mathrm{~km}$, the location of the rawinsonde launch site projected on this plane. The difference of the mean wind speed and the mean horizontal velocity was about $1 \mathrm{~m} / \mathrm{s}$, which can be attributed to the change of wind direction over the topography.

Snow particles with small falling velocities can be considered as the approximate tracer of airflow. Contour lines of relative frequency of reflectivity Level 1 (Fig. 12a) lowered abruptly at $z>2 \mathrm{~km}$ above the Dewa Hills. This indicates the decrease of mean echo-top height. The decrease suggests that the downward airflow existed continuously for the five hours.

The decrease of echo-top height also appeared in the time series of echoes. Figure 14 threedimensionally shows an example of the echoes by the isosurface at $13 \mathrm{dBZe}$. A massive snow echo, indicated by a thick arrow, moved eastward (from left to right in the figure) with the echo-top height decreased over the Dewa Hills and recovered on the lee side. The echo appeared in the west part of the radar coverage at 1854JST. The echo top was suppressed at (S-N Distance) $<15 \mathrm{~km}$ as the echo moved to the east (1859JST, 1905JST). The echo-top height partially recovered when the echo moved farther eastward (1910JST, 1915JST). We can not determine the echo-top height around the radar zenith and in the shadow area because of the lack of data.

It is noted that the echo-top height evidently decreased at a fixed line along (W-E Distance) = $-23 \mathrm{~km}$ from 1419JST to 2245JST, suggesting that the suppression of the echo top reflects the orographically-induced downward motion over the mountain barrier. The recovery of the echo top occurred at $(\mathrm{W}-\mathrm{E}$ Distance $)=-8 \mathrm{~km}$, or several kilometers westward. The suppression of echo top usually occurred at (S-N Distance) $<15 \mathrm{~km}$, and sometimes at (S-N Distance) $<20 \mathrm{~km}$, though it limited at $(\mathrm{S}-\mathrm{N}$ Distance $)<15 \mathrm{~km}$ in Fig. 14. The echo-top height at (S-N Distance) $>20 \mathrm{~km}$ is not discussed in this paper because the effect of other mountains (see the right-bottom panel of Fig. 14) must be considered.

The echo top height decreased over the Dewa Hills and increased to the leeward. Some model simulations showed that the fall speed of the snow particles can be almost offset by the updraft speed as the air flows over the barrier (Cotton and Anthes, 1989; Hobbs et al., 1973). The particle motion is the sum of the small fall speed of snow particles (corresponds to weak reflectivity) and downward and upward airflow formed kinematically by the orographic effect. The contour lines of relative frequency near the echo top did not change on the lee side in Fig. 12a. The increase of echo-top height is seen at (W-E Distance) $=-8 \mathrm{~km}$ in Fig. 14. They indicate that the upward airflow was formed between the Dewa Hills and another mountain barrier existing several tens of kilometer to the leeward of the Dewa Hills.

\section{Discussion}

a. Decrease in the depth of the mixed layer above the Dewa Hills

Here, we discuss the change in the mixed-layer depth qualitatively using the sounding and surface data (Fig. 15), assuming two-dimensionality. We used the sounding data at Sakata at 1603JST for the potential temperature. Wind data of this sounding 

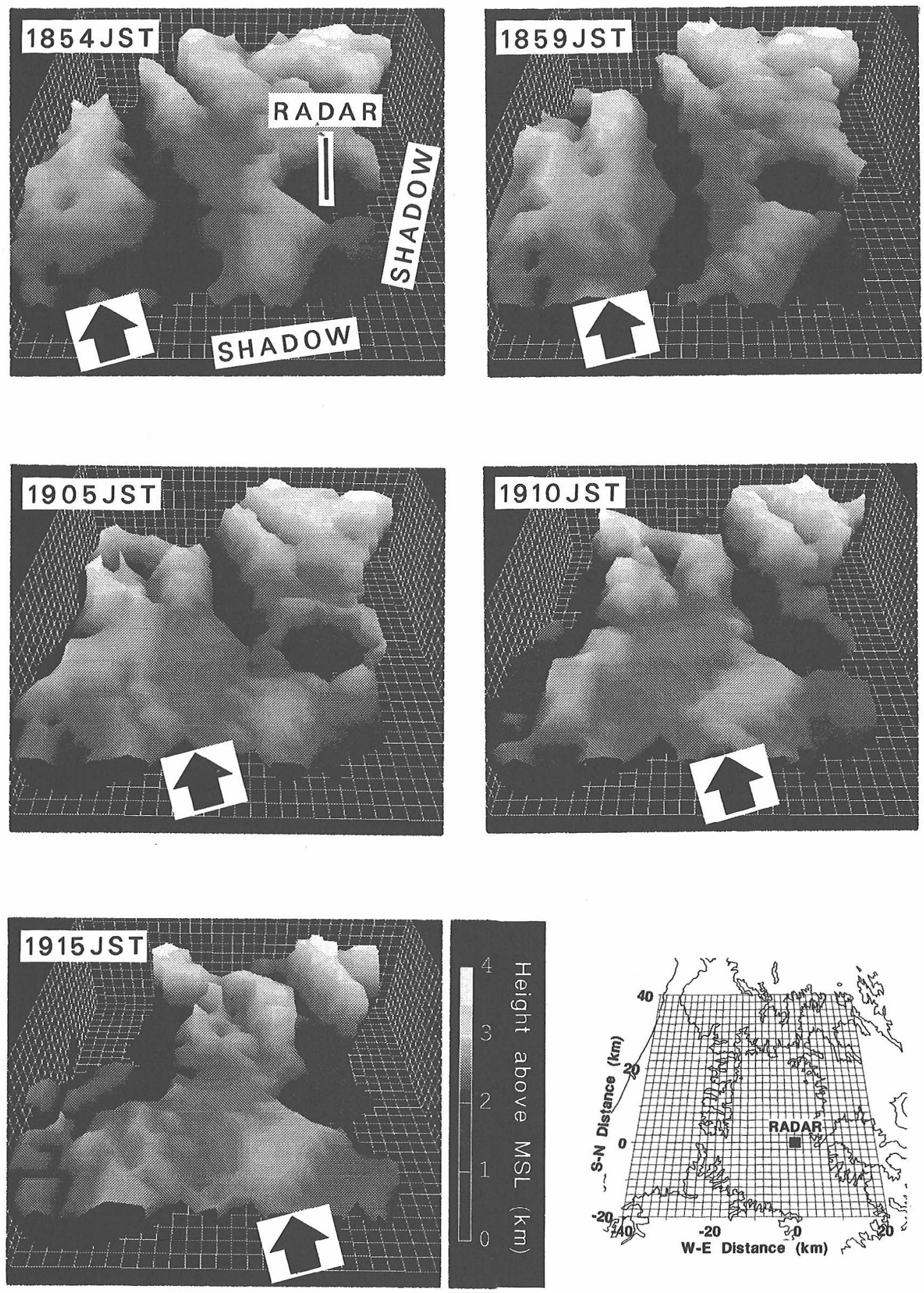

Fig. 14. Three-dimensional display of a sequence of volume data of reflectivity. The panel at the right bottom shows the area displayed on the other panels. The other five panels show the isosurface at 13dBZe. The surface is gradated by the height above MSL. A massive echo is traced by thick arrows.

was so noisy that, instead, we used the sounding data at Sakegawa at 1600JST, and surface data at Sakata at 1600JST for the wind speed. The wind speed below $1.5 \mathrm{~km}$ was derived interpolating these data between the height of $1.5 \mathrm{~km}$ and the surface.

The Froude number $(F r)$ was calculated under a simplified condition to examine the characteristics of the mixed layer. Fr, characterizing the two- 


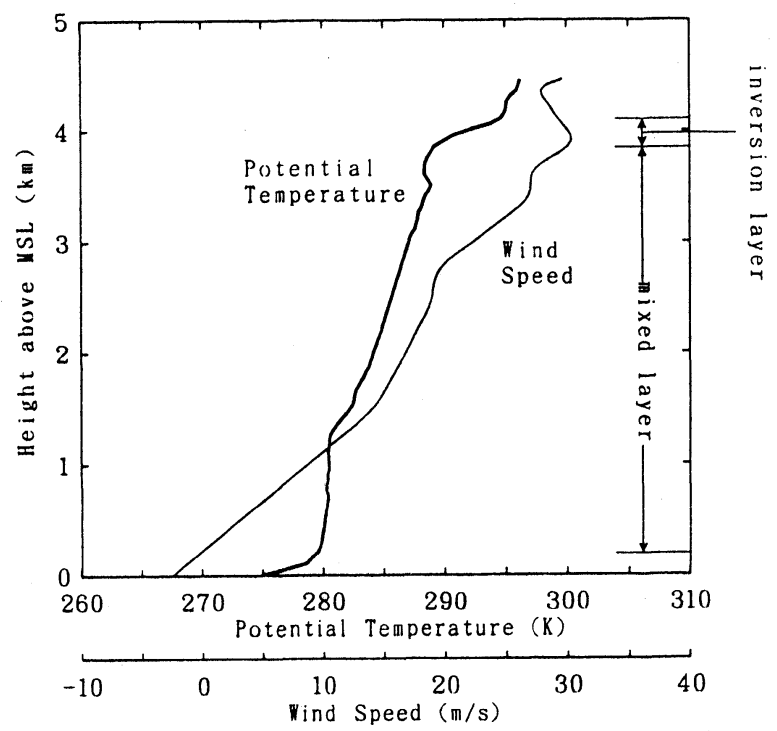

Fig. 15. Potential temperature $(\theta)$ and wind component perpendicular to the running direction of the Dewa Hills $(U)$.

dimensional flow in a two-layered fluid divided by discontinuity passing over a mountain (e.g., Cotton and Anthes (1989)), is described as

$$
F r^{2}=\frac{U^{2}}{\frac{\theta^{\prime}-\theta}{\theta^{\prime}} g \cdot h},
$$

where $U$ is the velocity, $h$ the $\operatorname{depth}, \theta$ the potential temperature of the lower layer, $g$ is the gravitational constant and $\theta^{\prime}$ is the potential temperature of the upper layer; $\theta$ and $\theta^{\prime}$ are assumed to be uniform in each layer. $U$ and $h$ are dependent only on the horizontal distance, although the characteristics of the flow are determined by the initial values. The inversion layer and the mixed layer for this calculation were defined as shown in Fig. 15. The potential temperature at the top of the inversion layer (i.e., the bottom of the upper layer) was used for $\theta^{\prime}$. The mixed layer was defined between $0.19 \mathrm{~km}$ and $3.85 \mathrm{~km}$ from the temperature profile. The average values of the mixed layer were used for $U$ and $\theta$. The values of $U, \theta, \theta^{\prime}$ and $h$ are $15.9 \mathrm{~m} / \mathrm{s}, 284 \mathrm{~K}, 295 \mathrm{~K}$ and $3653 \mathrm{~m}$, respectively.

If a steady-state solution exists, the flow pattern is classified into two types according to the values of $F r$. When $F r<1$, it is called 'subcritical' and the height of the discontinuity decreases over the mountain and recovers leeward. When $F r>1$, it is called 'supercritical', and the height of the discontinuity increases over the mountain and recovers leeward. A steady-state solution does not exist for some combinations of $F r, h$, and the depth of the lower layer. In this case, the flow is asymmetric with respect to the mountain and a hydraulic jump occurs.
The result was $F r=0.44$ and in the régime of 'subcritical', that is, the mixed-layer top dipped over the Dewa Hills. This is consistent with the evidence mentioned in Section 4, although water vapor, clouds and precipitation existed in the actual situation. This suggests that the mean flow over the Dewa Hills in this case is explained based on the behavior of shallow water that flows over an obstacle, and that convection and microphysical processes modified the basic flow only slightly. Durran and Klemp (1982) showed that the mountain waves were significantly affected by condensation. The flow pattern may fluctuate during the passage of each snow cloud. However, the basic feature of the mixed-layer was not influenced significantly by the snow clouds in this case.

The height of the mixed-layer top around 16JST, defined by the temperature inversion aloft, was $3.85 \mathrm{~km}$ at Sakata and $3.56 \mathrm{~km}$ at Sakegawa (Fig. 16). This difference may be due partially to the decay of the mixed layer over the land, and partially to the incomplete recovery of the lowered mixed-layer top. The top boundary of the shallow water lowered over an obstacle recovers at a point sufficiently to the leeward. However, there are other mountain ranges to the leeward of the observation area and the altitude on the lee side does not recover to the sea level immediately, that may be related to the incomplete recovery of the mixed-layer top.

\section{b. Precipitation mechanisms}

We showed that the precipitation enhancement occurred over and as far as $10 \mathrm{~km}$ upwind of the Dewa Hills. However, the mixed layer was slightly stable both at Sakata and at Sakegawa (Fig. 16). The existing convection could not strengthen and new convection could not generate, even if forced upward motion caused condensation and warming over the Dewa Hills.

Specific humidity $(q)$ at Sakegawa was smaller than that at Sakata below the height of $2 \mathrm{~km}$. Considering that the wind blew from Sakata to Sakegawa, the water vapor decreased between the two points, that is, over the Dewa Hills. The precipitable water in the mixed layer was calculated by

$$
\int_{\text {mixed layer top }}^{\text {ground }} \frac{q}{g} d p .
$$

The precipitable water on the windward side was $8.43 \mathrm{~mm}$ and that on the lee side was $7.24 \mathrm{~mm}$. The decrease of water vapor over the Dewa Hills was $1.19 \mathrm{~mm}$. We saw in Section 4 that the precipitation enhancement over the Dewa Hills occurred below the height of $2 \mathrm{~km}$. This indicates that the water vapor is used for the precipitation enhancement resulting in the increase of reflectivity shown in Fig. 12. It is suggested that the orographic updraft led to the formation of low-level clouds over 


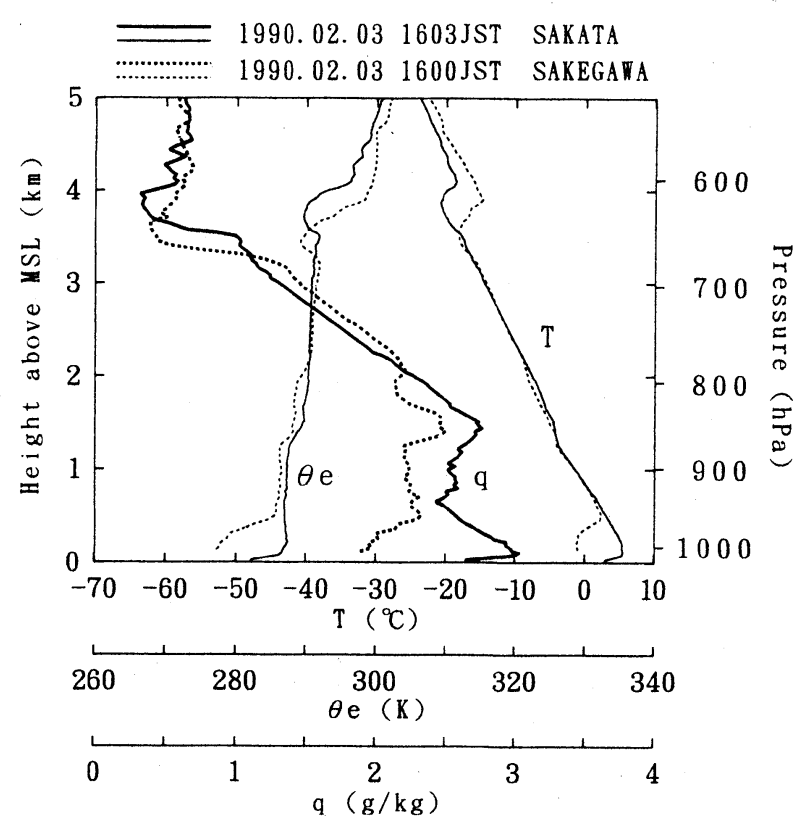

Fig. 16. Specific humidity $(q)$ and equivalent potential temperature $\left(\theta_{e}\right)$ profiles at 16JST based on simultaneous rawinsonde observations at Sakata and Sakegawa.

the Dewa Hills, and that a seeder-feeder mechanism worked between the orographic cloud and the snow clouds. Murakami et al. (1994b) also suggested, based on the result of numerical experiments, that the seeder-feeder mechanism operated well over the mountain in the snow clouds developed in the winter monsoon conditions. This observation did not include in situ observation of snow particles around the Dewa Hills. We cannot know whether the precipitation enhancement was by diffusion growth or riming growth, for either of the two processes can increase reflectivity.

There was almost no difference in the temperature between Sakata and Sakegawa, except in the lowest layer (Fig. 16). At Sakegawa, cold air existed below the height of $0.5 \mathrm{~km}$ (Fig. 16), and the wind was especially weak below the height of $0.4 \mathrm{~km}$ (Fig. 10a). The air near the ground was not convectively mixed with the air above. It is likely that the colder air that formed the land breeze remained in the lowest layer on the lee side. Snow particles may lose their mass by sublimation in the sinking flow on the lee side of a mountain. In this case, however, the colder air prevented the airflow from sinking to the lowest level and the precipitation was not reduced by this process. The reflectivity increased below the height of $1.5 \mathrm{~km}$ (Fig. 12). Snowflakes were mainly observed at the radar site. It is considered that the snow particles grew mainly by aggregation in the favorable temperature condition below the height of
$1.5 \mathrm{~km}$ (Fig. 16). Melting also occurred in the lower mixed layer and sometimes the precipitation at the radar site changed to sleet and rain. These processes increased reflectivity, however, they did not influence the precipitation amount significantly.

The seeder-feeder process enhanced the snowfall and the cold air remaining in the lowest layer prevented the reduction of snowfall on the lee side. This can be a mechanism that increases the snowfall of the inland areas located on the lee side of a low mountain barrier.

\section{Summary and conclusions}

The characteristics of a sequence of snow clouds passing over the Dewa Hills on 3 February 1990 were investigated using a Döppler radar and simultaneously launched rawinsondes on both sides of the Dewa Hills. The snow clouds accompanied a cold front occluded by the retreating front of the colder land breeze. The colder air remained over the inland basin and prevented the descending flow from being formed on the lee side of the Dewa Hills.

The pattern of echo-top height and the distribution of relative frequency suggest that the height of cloud top decreased over the Dewa Hills. The Froude number calculated from the sounding and surface data assuming two-dimensionality indicates the flow was 'subcritical'. Figure 17 illustrates schematically the characteristics of the flow and the snow clouds. The mixed-layer top was lowered and the wind was accelerated over the Dewa Hills. The lowered top boundary resulted in the descending flow that suppressed the cloud- and echo-top height. Ascending flow was generated in the upper mixed layer where the height of the mixed-layer top recovered, leading to the increase of the cloud- and echo-top height. The snow clouds did not overshoot the top boundary.

The snow clouds appeared in the radar data as echoes whose sizes were a few to several tens of kilometers. The echoes that passed over the Dewa Hills had similar velocities. The mean speed and direction were $17.2 \mathrm{~m} / \mathrm{s}$ and $81.0^{\circ}$ and they agreed with. the wind at the height of $2.2 \mathrm{~km}$. They contained the cells whose sizes were $5 \mathrm{~km}$ to $10 \mathrm{~km}$. Each cell moved forward relative to the echo including the cell, and the cell was accelerated by $3 \mathrm{~m} / \mathrm{s}$ when it was over the Dewa Hills. The speed of each cell was faster than the wind speed; however, the increase in both speeds was similar. The acceleration of the cells resulted in the distortion of the echoes and the fluctuation of the motion of the echoes. The increase of the wind speed is a characteristic of 'subcritical' flow. It is considered that the increase of the wind speed was an expression of 'subcritical' flow, and that the acceleration of the cells was an orographic effect caused by the Dewa Hills. The convection and microphysical process did not modify the mean 


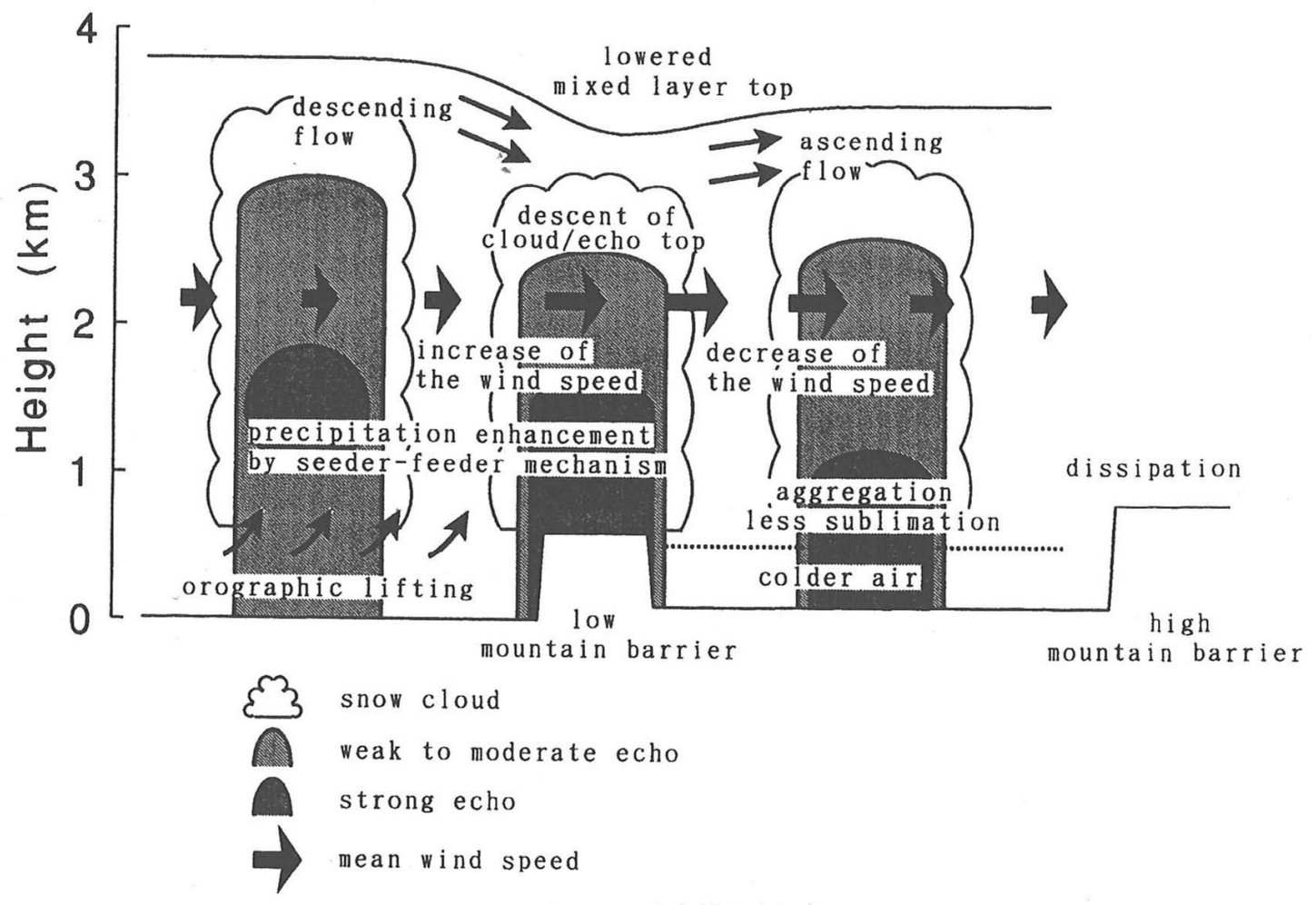

Fig. 17. Schematic illustration of snow clouds and airflow around the Dewa Hills.

'subcritical' flow over the Dewa Hills significantly.

The precipitation enhancement, that is expressed as the increase of strong echoes (more than 20dBZe), occurred as far as $10 \mathrm{~km}$ upwind of the Dewa Hills and up to the height of $2.0 \mathrm{~km}$ on the analyzed vertical plane. It was caused by a seeder-feeder mechanism between the snow clouds, as the seeder cloud, and the clouds formed by the orographic lifting as the feeder cloud. The cold air remaining in the lowest layer prevented the reduction of snowfall by sublimation on the lee side. It is considered that these processes contribute to increase snowfall of the inland areas located on the lee side of a low mountain barrier. A gradual increase of reflectivity was observed on the lee side, which was attributed to the increase of larger snow particles by aggregation. Temperature exceeded $0^{\circ} \mathrm{C}$ above the colder air near the ground on the lee side. Melting occurred at this height and the ground precipitation sometimes changed to the liquid phase. These processes increased the reflectivity but not the precipitation amount.

In this paper, we presented a case study of the snow clouds passing over a low mountain barrier. In this case, the behavior of the snow clouds was strongly affected by the flow over the low mountain barrier, while the mean flow was not significantly modified from 'subcritical' flow by the existence of the snow clouds. However, it is not clear how and to what extent each snow cloud modifies the mean orographic flow. The processes described in this paper can often occur around a low mountain barrier such as exists at many places in northern Japan. So far, there are few reports about the interaction of orographic flow and snow clouds. Case studies in other conditions, e.g., strong/weak cold outbreak, or a band cloud, are needed to clarify the mechanism of snowfall in mountainous areas of northern Japan, and hence posibly help to prevent the disasters caused by heavy snowfall in mountainous areas.

\section{Acknowledgments}

The authors would like to thank Dr. T. Matsuo of the Japan Meteorological Agency and Dr. H. Sakakibara of the Meteorological Research Institute for their encouraging comments and discussions, Dr. M. Murakami, Mr. H. Mizuno and Mr. Y. Yamada of Meteorological Research Institute for their discussions and support in making the observations, and two anonymous reviewers for their valuable and constructive comments. They also thank the personnel of the Shinjo City Hall and the Sakegawa Village Office of Yamagata Prefecture, and Sakata Construction Work Office of the Ministry of Construction for their cooperation in the observations. Part of this work was conducted under the research project "Study on Precipitation Formation in Snow Clouds and Feasibility of Snow Cloud Modification by Seeding" sponsored by Science and Technology 
Agency of Japan. The Döppler radar data were processed mainly using ACOS830 of NIED.

\section{References}

Bruintjes, R.T., T.L. Clark and W.D. Hall, 1994: Interactions between topographic airflow and cloud/precipitation development during the passage of a winter storm in Arizona. J. Atmos. Sci., 51, 48-67.

Cotton, W.R. and R.A. Anthes, 1989: Storm and cloud dynamics. Academic Press. 883 pp.

Durran, D.R. and J.B. Klemp, 1982: The effects of moisture on trapped mountain lee waves. J. Atmos. Sci., 39, 2490-2506.

Fujiyoshi, Y., K. Tsuboki, S. Satoh and G. Wakahama, 1992: Three-dimensional radar echo structure of a snow band formed on the lee side of a mountain. $J$. Meteor. Soc. Japan, 70, 11-24.

Hobbs, P.V., R.C. Easter and A.B. Fraser, 1973: A theoretical study of the flow of air and fallout of solid precipitation over mountainous terrain: Part II. Microphysics. J. Atmos. Sci., 30, 813-823.

Ikawa, M., H. Mizuno, T. Matsuo, M. Murakami, Y. Yamada and K. Saito, 1991: Numerical modeling of the convective snow cloud over the Sea of Japan Precipitation mechanism and sensitivity to ice crystal nucleation rates - J. Meteor. Soc. Japan, 69, 641-667.

Ishihara, M., H. Sakakibara and Z. Yanagisawa, 1989: Doppler radar analysis of the structure of mesoscale snow bands developed between the winter monsoon and the land breeze. J. Meteor. Soc. Japan, 67, 503520.

Kikuchi, K., S. Azumane, M. Murakami and T. Taniguchi, 1987: Precipitating snow clouds during winter monsoon seasons influenced by topography of the Shakotan Peninsula, Hokkaido Island, Japan (SHAROP). Environ. Sci., Hokkaido, 10, 109-128.

Klemp, J.B. and D.K. Lilly, 1975: The dynamics of wave-induced downslope winds. J. Atmos. Sci., 32, 320-339.

Klemp, J.B. and D.K. Lilly, 1978: Numerical simulation of hydrostatic mountain waves. J. Atmos. Sci., 35, 78-107.

Maki, M. and T. Yagi, 1987: Radar observations of snowfall in 1986 over the Shinjo Basin - Features of vertical structures - (Japanese with English abstract). Rep. Natl. Res. Cent. Disast. Prev., No. 39, $1-17$.

Maki, M., T. Yagi and S. Nakai, 1989: The Doppler radar of NRCDP and observations of meso-scale weather systems. Rep. Natl. Res. Cent. Disast. Prev., No. 44, 61-79.

Meischner, P., M. Hagen and V.N. Bringi, 1992: Microphysics of snow formation of an alpine upslope case. Proceedings, 11th International Conference on Clouds and Precipitation, August 17-21, 1992, Montreal, Canada, 200-203.

Meyers, M.P. and W.R. Cotton, 1992: Evaluation of the potential for wintertime quantitative precipitation forecasting over mountainous terrain with an explicit cloud model. Part I: Two-dimensional sensitivity experiments. J. Atmos. Sci., 31, 26-50.
Murakami, M., T. Matsuo, H. Mizuno and Y. Yamada, 1994a: Mesoscale and microscale structures of snow clouds over the Sea of Japan. Part I: Evolution of microphysical structures in short-lived convective snow clouds. J. Meteor. Soc. Japan, 72, 671-694.

Murakami, M., T.L. Clark and W.D. Hall, 1994b: Numerical simulations of convective snow clouds over the Sea of Japan; Two-dimensional simulations of mixed layer development and convective snow cloud formation. J. Meteor. Soc. Japan, 72, 43-62.

Nakai, S., M. Maki and T. Yagi, 1990: Doppler radar observation of orographic modification of snow clouds - A case of enhanced snowfall - (Japanese with English abstract). Rep. Natl. Res. Cent. Disast. Prev., No. 45, 1-16.

Nakai, S. and T. Endoh, 1992: Radar echo morphology and airflow influenced by a mountain range in winter monsoon period - A case of cold frontal precipitation - (Japanese with English abstract). Rep. Natl. Res. Inst. Earth Sci. Disast. Prev., No. 50, 1-23.

Rauber, R.M., 1992: Microphysical structure and evolution of a central Sierra Nevada orographic cloud system. J. Appl. Meteor., 31, 3-24.

Rikiishi, K., J. Sugaya and H. Maeda, 1989: On the characteristics of snowfall at Aomori City (Japanese with English abstract). Seppyo, 51, 253-264.

Sakakibara, H., M. Ishihara and Z. Yanagisawa, 1988: Squall line like convective snowbands over the Sea of Japan. J. Meteor. Soc. Japan, 66, 937-953.

Sanpei, J. and N. Kawazoe, 1976: Changes in radar echo patterns over the Japan-Sea side of the Tohoku District associated with the passage of cold dome in winter season (Japanese with English abstract). $J$. Meteor. Res., 28, 189-200.

Smith, R.B., 1979: The influence of mountains on the atmosphere. Adv. Geophys., 21, 87-230.

Takeda, T., K. Isono, M. Wada, Y. Ishizaka, K. Okada, Y. Fujiyoshi, M. Maruyama, Y. Izawa and K. Nagaya, 1982: Modification of convective snow-clouds in landing the Japan Sea coastal region. J. Meteor. Soc. Japan, 60, 967-977.

Tsuboki, K., Y. Fujiyoshi and G. Wakahama, 1989: Doppler radar observation of convergence band cloud formed on the west coast of Hokkaido Island. II: cold frontal type. J. Meteor. Soc. Japan, 67, 985-999.

Uttal, T., R.M. Rauber, L.O. Grant, 1988: Distributions of liquid, vapor, and ice in an orographic cloud from field observations. J. Atmos. Sci., 45, 1110-1122.

Uyeda, H. and T. Yagi, 1987: Radar observations of snowfalls in 1985 over the Shinjo Basin - vertical scanning -. J. Fac. Sci., Hokkaido Univ., Ser. VII(Geophysics), 8, 121-136.

Yagi, S. and Y. Uchiyama, 1983: Cloud movement and confluence around Noto Peninsula and Sado Island in relation to heavy snowfall over Johetsu area (in Japanese). Tenki, 30, 291-294.

Yamada, Y., T. Matsuo, M. Murakami and H. Mizuno, 1994: Mesoscale and microscale structures of snow clouds over the Sea of Japan. Part II: Time change in airflow structures in isolated snow clouds derived from dual-Döppler radar observations - A case study -. J. Meteor. Soc. Japan, 72, 695-708. 


\title{
丘陵地形上の降雪と気流に関する観測的研究
}

\author{
中井専人
}

(防災科学技術研究所)

遠藤辰雄

(北海道大学低温科学研究所)

降雪雲が丘陵地形 (出羽丘陵; 棱線の標高約 $0.6 \mathrm{~km}$ ) を越える時の降雪と気流の特徵を明らかにするた め、ドップラーレーダーとレーウィンゾンデによる観測を行った。1990 年 2 月 3 日の寒冷前線の通過に 伴って降雪雲が現れ、約 5 時間にわたって直径数十 $\mathrm{km}$ のエコーがいくつも出羽丘陵上を通過した。これ らのエコーのエコー頂高度は丘陵上で低くなっていた。丘陵を通過する流れは 'subcritical'であり、混合

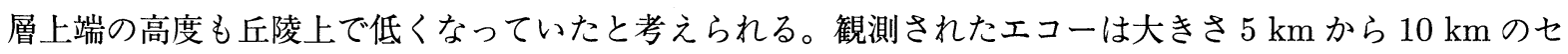
ルを含んでおり、これらのセルの移動速度は丘陵上で $3 \mathrm{~m} / \mathrm{s}$ 増加していた。丘陵上から $10 \mathrm{~km}$ 風上までの 範囲で上空の降水強度の増加が見られ、降雪雲と地形性上昇によって形成された雲との間で seeder-feeder mechanism が㗢いていたと考えられる。丘陵風下においては下層に冷気がたまっていたため斜面を下降す る流れが形成されず、昇華による降水量の減少が抑えられていた。丘陵風下においても反射強度の増加が みられたが、これは主に降雪粒子の併合成長と融解によるものであり、降水量はあまり変化していなかっ たと考えられる。この事例では降雪雲の振る舞いは丘陵による地形性の流れに強く影響されていたが、平 均的な気流に対する降雪雲の影響はそれほど大きくはなかった。 